\title{
ASBESTOS EXPOSURE, LEGISLATION AND DISEASES IN THE CZECH REPUBLIC
}

\author{
Daniela Pelclová1, Zdenka Fenclová1,2, Pavel Urban ${ }^{1,2}$ \\ ${ }^{1}$ Department of Occupational Medicine, Charles University, Prague \\ ${ }^{2}$ National Institute of Public Health, Prague
}

\begin{abstract}
SUMMARY
Asbestos manufacturing has been banned in the Czech Republic; however, about 280 workers in the 2nd-4th work category have been exposed during the remediation of asbestos, and the health consequences of the former use of asbestos will be apparent for many years. The incidence of mesothelioma in the Czech Republic is about 0.5/100,000 inhabitants, which places it among the lowest incidences of mesothelioma in Europe, and ranks the Czech Republic among the countries with the lowest rates in the world. The proportion of occupational mesotheliomas is only about one-tenth of these malignancies. These data show an underreporting of occupational cancers, most probably due to low awareness of the association of exposures more than 40 years ago with this disease. Physicians should focus more on the occupational history of these patients and refer them to the Departments of occupational diseases. Benefits are available for all patients with mesothelioma, in whom industrial hygienists confirm former exposure to asbestos, corresponding to the latency period.
\end{abstract}

Key words: asbestos, mesothelioma, incidence, exposure, remediation

Address for correspondence: D. Pelclová, Department of Occupational Medicine of the First Medical Faculty, Charles University, Na Bojišti 1 , 12000 Prague, Czech Republic. E-mail: daniela.pelclova@lf1.cuni.cz

\section{INTRODUCTION}

Asbestos-induced diseases include asbestosis, pleural hyalinosis, lung cancer and mesothelioma (Fig. 1). The occurrence of mesothelioma differs among countries. Its origin is usually related to asbestos exposure as the most significant factor. More than $80 \%$ of mesotheliomas develop in individuals with higher than background exposure to asbestos, with an incidence as high as $366 / 100,000$ personyears in heavily exposed workers (1).

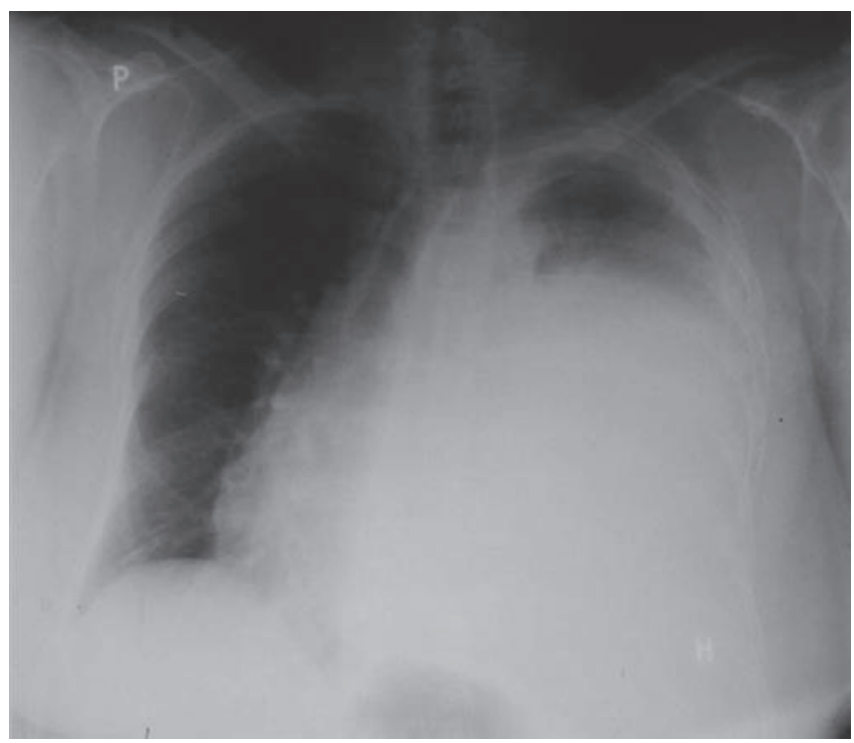

Fig. 1. Mesothelioma.
Very frequently the mesothelioma is under-reported. The first reference from Czech territory to the health risk run by workers spinning asbestos textile fibres to produce heat insulants was already in 1897 by Netolitzky (2), when Czech Republic was part of the Austro-Hungarian Monarchy. However, recent data on mesotheliomas in the Czech population have not been published and are missing in the international review (3). The aim of this paper was to describe the recent situation concerning exposure to asbestos and to compare the incidence of mesothelioma in the general Czech population with the incidence of mesothelioma reported as an occupational disease.

Out of the population of the Czech Republic of about 10 million, a total of 5 million are workers, of whom about 405,500 (8\%) are subject to hazardous occupational exposure (4).

Under Czech legislation, asbestos has been classified as a carcinogen since 1984. After 1997, new production of asbestos-containing materials was no longer permitted, and the manufacture of asbestos in older plants was down-regulated. Buildings constructed after that date cannot contain asbestos. Governmental Order No. 432/2003 limited the maximal allowed concentration (MAC) of both chrysotile and amphibole fibres to $0.1 \mathrm{fibre} / \mathrm{ml}$ as of 15 April 2006, in accordance with other EU member states.

A system of categorization of work operations, including exposure to asbestos, was established in the Czech Republic in 2001 for the purposes of occupational health inspection. The system is based on the monitoring of various harmful factors (chemical, physical, biological) in the workplace. The work operations are divided into four categories, with category 1 being the best, i.e. with the lowest risk, ranked according 
to specific criteria by the extent of risk. The category of the work operation and the most important risk factors determine the frequency and scope of periodic medical examinations of workers in that category. In the first category, asbestos fibre concentration must not exceed $30 \%$ of the MAC; in the second category, it must not exceed the MAC; and in the third category the concentration must not exceed the treble of the MAC. All work in which asbestos fibre concentration exceeds the treble of the MAC is classified as the fourth category.

Occupational medicine originated in Czechoslovakia in 1932, and statistical data on the incidence of occupational diseases have been collected in the country since the 1950s (5). In 1991 the Czech National Registry of Occupational Diseases was founded at the Centre of Occupational Health at the National Institute of Public Health in Prague. There are 20 items of information reported with regard to each case, e.g. the identification data of the patient, diagnosis, age, gender, occupation, length of exposure, etc. All the data are available on-line for decision-makers (6).

Occupational diseases or intoxications, and the hygienic and medical conditions under which they are acceptable as such, are given in the List of Occupational Diseases (Governmental Order No. 290/1995), based on a model list of occupational diseases elaborated by the ILO.

Departments of occupational diseases deal with the diagnosis, treatment and rehabilitation of occupational diseases; they also provide periodic examination of workers from hazardous workplaces. They are entitled to confirm and notify occupational diseases, and to take decisions concerning compensation of occupational diseases. Payments are made according to the grade of severity and length of duration of the disease. Besides compensation for "pain and suffering" and "impaired life capacity", workers get benefits for "lost wages" due to short-term or long-term inability to perform their previous jobs (7).

Table 1. Employees exposed to asbestos in the Czech Republic (updated in September 2006)

\begin{tabular}{|c|l|}
\hline Asbestos exposure & No. of employees \\
\hline Category & Total \\
\hline 2 & 217 \\
\hline 3 & 44 \\
\hline 4 & 19 \\
\hline Total & $\mathbf{2 8 0}$ \\
\hline
\end{tabular}

An occupational disease or intoxication cannot be reported without being supported by an appropriate hygienist's report. According to Czech legislation, asbestosis can be acknowledged starting from the finding $\mathrm{s} 2, \mathrm{t} 2$ or $\mathrm{u} 2$ according to ILO classification (8) of chest radiographs. Pleural hyalinosis can be acknowledged, assuming that the patient has lung function impairment (9), lung cancer in case of accompanying pleural hyalinosis and/or asbestosis. For mesothelioma, no additional criteria have been formulated.

\section{METHODS}

Data on work categories with asbestos were selected from the database "Categories of work operations"; the numbers of occupational diseases acknowledged in the Czech Republic were found in the Czech National Registry of Occupational Diseases. These data were compared with the Czech statistical data from the Healthcare Statistical Registry (10).

\section{RESULTS}

The current total number of employees exposed to asbestos in the Czech Republic is 280 (updated on September 2006). The distribution of work involving asbestos exposure is shown by category in Table 1 . The workers were exposed to asbestos either during complete asbestos removal from buildings or during the remediation of buildings and equipment.

Occupational diseases due to asbestos acknowledged in the last year (2005) are shown in Table 2. All occupational diseases, all cancers in the population and occupational cancers including mesotheliomas acknowledged in the Czech Republic are presented in Tables 3 and 4.

\section{DISCUSSION}

The incidence of mesothelioma in the Czech Republic is about 5 per million (i.e. $0.5 / 100,000$ ) inhabitants, which places it in the lowest range of mesothelioma incidence in Europe, and ranks the Czech Republic among the countries with the lowest rates in the world. The incidence in the Czech Republic lies between Romania with 6 and Slovakia, Estonia, Macedonia and Spain with 4 cases per million (3). The Czech Republic has never been a producer of

Table 2. Selected demographic data on subjects with acknowledged occupational diseases due to asbestos in 2005

\begin{tabular}{|c|c|c|c|c|}
\hline Diagnosis & No. & Men/Women & $\begin{array}{c}\text { Age } \\
\text { (years) } \\
\text { Median and range }\end{array}$ & $\begin{array}{c}\text { Exposure } \\
\text { (years) } \\
\text { Median and range }\end{array}$ \\
\hline Asbestosis & 9 & $4 / 5$ & $\begin{array}{c}63 \\
(54-72) \\
\end{array}$ & $\begin{array}{c}28 \\
(7-35) \\
\end{array}$ \\
\hline Pleural hyalinosis with lung function impairment & 23 & $15 / 8$ & $\begin{array}{c}72 \\
(47-88)\end{array}$ & $\begin{array}{c}27 \\
(2-36)\end{array}$ \\
\hline Mesothelioma & 8 & $5 / 3$ & $\begin{array}{c}61.5 \\
(52-83)\end{array}$ & $\begin{array}{c}27 \\
(10.5-39)\end{array}$ \\
\hline Lung cancer with asbestosis or pleural hyalinosis & 2 & $2 / 0$ & $\begin{array}{c}66 \\
(62-70)\end{array}$ & $\begin{array}{c}22,7 \\
(22-23.4)\end{array}$ \\
\hline
\end{tabular}


Table 3. All occupational diseases, all cancers in the population and occupational cancers acknowledged in the Czech Republic in the period 1991-2005

\begin{tabular}{|c|c|c|c|c|c|c|c|c|c|c|c|c|c|c|c|c|}
\hline & \multicolumn{15}{|c|}{ Year } & \multirow{2}{*}{ Total } \\
\hline & 1991 & 1992 & 1993 & 1994 & \begin{tabular}{|l|}
1995 \\
\end{tabular} & 1996 & 1997 & \begin{tabular}{|l|}
1998 \\
\end{tabular} & 1999 & 2000 & 2001 & 2002 & 2003 & 2004 & 2005 & \\
\hline $\begin{array}{l}\text { Occupational } \\
\text { diseases }\end{array}$ & 8,603 & 3,393 & 2,983 & 2,675 & 2,806 & 2,519 & 2,350 & 2,054 & 1,845 & 1,691 & 1,627 & 1,531 & 1,486 & 1,329 & 1,340 & 38,232 \\
\hline $\begin{array}{l}\text { All } \\
\text { cancers }\end{array}$ & 47,313 & 49,235 & 51,495 & 53,493 & 54,628 & 56,981 & 58,148 & 58,553 & 59,823 & 59,514 & 61,460 & 64,525 & 66,637 & 68,641 & $x$ & 741,805 \\
\hline $\begin{array}{l}\text { Occupational } \\
\text { cancers }\end{array}$ & 100 & 77 & 99 & 83 & 65 & 74 & 66 & 37 & 41 & 50 & 56 & 49 & 45 & 26 & 39 & 907 \\
\hline $\begin{array}{l}\text { Incidence of } \\
\text { occupational } \\
\text { diseases } \\
/ 100,000 \text { insured }\end{array}$ & 182.6 & 72.0 & 63.3 & 56.2 & 59.6 & 54.7 & 48.6 & 42.9 & 40.3 & 37.4 & 36.3 & 34.3 & 33.5 & 30.3 & 30.2 & \\
\hline $\begin{array}{l}\text { Incidence of } \\
\text { cancers } \\
/ 100,000 \text { inhabi- } \\
\text { tants }\end{array}$ & 459 & 477 & 498 & 517 & 528 & 552 & 564 & 568 & 581 & 579 & 601 & 632 & 653 & 673 & $x$ & \\
\hline $\begin{array}{l}\text { Incidence of } \\
\text { occupational } \\
\text { cancers } \\
/ 100,000 \text { insured }\end{array}$ & 2.1 & 1.6 & 2.1 & 1.7 & 1.4 & 1.6 & 1.4 & 0.8 & 0.9 & 1.1 & 1.3 & 1.1 & 1.0 & 0.6 & 0.9 & \\
\hline
\end{tabular}

$\mathrm{x}$ - data not available

Table 4. Asbestos-induced occupational disorders acknowledged in the Czech Republic, and total number of mesotheliomas in the Czech Republic in the period 1991-2005

\begin{tabular}{|c|c|c|c|c|c|c|c|c|c|c|c|c|c|c|c|}
\hline \multirow{2}{*}{$\begin{array}{l}\text { Asbestos-induced } \\
\text { occupational } \\
\text { disorders }\end{array}$} & \multicolumn{15}{|c|}{ Year } \\
\hline & 1991 & 1992 & 1993 & 1994 & 1995 & 1996 & 1997 & 1998 & 1999 & 2000 & 2001 & 2002 & 2003 & 2004 & 2005 \\
\hline Asbestosis & 7 & 9 & 12 & 7 & 18 & 11 & 8 & 7 & 7 & 2 & 3 & 5 & 8 & 4 & 9 \\
\hline Pleural hyalinosis & - & - & - & - & - & 3 & 2 & 5 & 8 & 4 & 15 & 21 & 10 & 12 & 23 \\
\hline Lung cancer & 5 & 3 & 3 & 1 & 4 & 3 & 2 & 3 & 3 & 1 & 7 & 2 & 1 & 4 & 2 \\
\hline Mesothelioma & - & 1 & 1 & 2 & 2 & 1 & 8 & 4 & 5 & 7 & 7 & 6 & 5 & 3 & 8 \\
\hline Total & 12 & 13 & 16 & 10 & 24 & 18 & 20 & 19 & 23 & 14 & 32 & 34 & 24 & 23 & 42 \\
\hline $\begin{array}{l}\text { Total mesotheliomas } \\
\text { in the Czech Republic }\end{array}$ & 56 & 74 & 64 & 57 & 37 & 43 & 48 & 44 & 39 & 50 & 55 & 71 & 61 & 61 & $x$ \\
\hline
\end{tabular}

$x$ - data not available

asbestos; nevertheless, there used to be several asbestos manufacturing plants producing roofing material, pipes, insulation, textiles and other products. The "eternit" roofs are spread all around the country. In addition, asbestos-containing waste was not handled separately until 2001.

The more surprising fact is the low number of mesotheliomas acknowledged as occupational in the Czech Republic. It points to a low awareness among physicians of the fact that asbestos is the dominant cause of these malignancies. This association might be overlooked due to the long latency period after exposure to this mineral in an occupational environment, where asbestos use is not well known to all physicians (such as cutting asbestos-containing boards or ropes for insulation). Moreover, unlike in France or Belgium, there is no active association of victims of asbestos in the Czech Republic that would promote public awareness of the danger of asbestos, including housing in the proximity of factories and/or household contamination with asbestos.
The number of asbestos-induced occupational disorders in 2005, a total of 42 diseases, is likely to increase in the future due to the long latency of these diseases after exposure. Very probably, in the next decades, the incidence of asbestosis as an occupational disease will disappear in the Czech Republic; however, the incidence of pleural hyalinoses, lung cancer and mesothelioma is expected to rise (11), especially because the estimated number of patients with previous occupational exposure to asbestos is as high as 55,000 people (12). In addition to well known risks, more recent data point to the association with antineutrophil cytoplasmic antibody (ANCA) positivity $(13,14)$.

Of course, a primary goal is the prevention of new asbestosinduced diseases and paying attention to working conditions. On the other hand, occupational asbestos-induced diseases can be compensated, assuming that clinical and hygienic criteria are fulfilled. The proportion of occupational mesotheliomas is only about one-tenth of all these malignancies. The data presented 
here establish the underreporting of occupational cancers due to low awareness of the association of exposures decades ago with current diseases (15). Physicians should focus more on the occupational history of these patients and refer them to centres of occupational diseases. Benefits are available to all patients with mesothelioma, in whom industrial hygienists confirm former exposure to asbestos, corresponding to the latency period.

\section{Acknowledgement}

This work was supported by a Project of the Ministry of Education MSM 0021620807. We would like to thank Professor Steve Diskin for the linguistic assistance.

\section{REFERENCES}

1. Carbone M, Kratzke RA, Testa JR. The pathogenesis of mesothelioma. Semin Oncol. 2002 Feb;29(1):2-17.

2. Netolitzky A. Hygiene der Textilindustrie. Handbuch der Hygiene. Jena: G. Fischer Verlag; 1897.

3. Giarelli L, Bianchi C, Bianchi T. Geography of mesothelioma. Eur J Oncol. 2003 Dec;8(4):253-8.

4. Paoli P, Parent-Thirion A, Persson O. Working conditions in candidate countries and the European Union. Luxembourg: Office for Official Publications of the European Communities; 2002.

5. Cikrt M, Pelclová D, Markvart K, Lukáš E, Kříž J. Occupational and environmental medicine in Czech Republic. Int Arch Occup Environ Health. 1997;69(2):79-82.

6. Urban P, Cikrt M, Hejlek A, Lukáš E, Pelclová D. The Czech National Registry of Occupational Diseases. Ten years of existence. Cent Eur J Public Health. 2000 Nov;8(4):210-2.
7. Pelclová D, Ameille J, Urban P, Fenclová Z, Lebedová J. Occupational diseases in the Czech Republic : purpose of the study. Arch Mal Prof. 2001;62(8):629-33. (In French.)

8. International Labour Organisation. Guidelines for the use of ILO international classification of radiographs of pneumoconiosis. Geneva: ILO; 1980.

9. Lebedová J, Dlouhá B, Rychlá L, Neuwirth J, Brabec M, Pelclová D, et al. Lung function impairment in relation to asbestos-induced pleural lesions with reference to the extent of the lesions and the initial parenchymal fibrosis. Scand J Work Environ Health. 2003 Oct;29(5):388-395.

10. Cancer incidence 1991-2003 in the Czech Republic. Health statistics. Prague: Institute of Health Information and Statistics of the Czech Republic; 1994-2006.

11. Lemen RA. Asbestos-related disease risks still exist. Eur J Oncol. 2005 Mar;10(1):9-30.

12. Šmerhovský Z, Landa K, Kauppinen T. CAREX - International information system of occupational exposure to carcinogens and its application in the Czech Republic. Ces Prac Lek. 2003;4(3):108-13. (In Czech.)

13. Pelclová D, Bartůn̆ková J, Fenclová Z, Lebedová J, Hladíková M, Benáková $\mathrm{H}$. Asbestos exposure and antineutrophil cytoplasmic antibody (ANCA) positivity. Arch Environ Health. 2003 Oct;58(10):662-8.

14. Ř́hová Z, Maixnerová D, Jančová E, Pelclová D, Bartůňková J, Fenclová $\mathrm{Z}$, et al. Silica and asbestos exposure in ANCA-associated vasculitis with pulmonary involvement. Ren Fail. 2005;27(5):605-8.

15. Fenclová Z, Šmerhovský Z, Urban P, Pelclová D, Dlouhá B. Analysis of the occurrence of profession-linked tumor diseases reported in the Czech Republic in the years 1991-2004. Prakt. Lek. 2006;86(1):19-24. (In Czech, English abstract.)

Received March 7, 2007 Received and accepted in revised form April 11, 2007 